\title{
Investigation of Serum and Wool Levels of Cobalt, Manganese, Selenium and Zinc in Liver-Trematode-Infected Sheep
}

\author{
Selçuk Seçkin TUNCER $^{1 *}$, Vural DENIZHAN² ${ }^{2}$, Süleyman KOZAT ${ }^{3}$ \\ 1V an Yuzuncu Yul University, Agricultural Faculty, Department of Animal Sciences, Van, Turkey \\ 2V an Yuzuncu Yul University, Özalp Vocational School, Department of Medical Laboratory Technician, Van, Turkey \\ ${ }^{3} \mathrm{~V}$ an Yuzuncu Yul University, Faculty of Veterinary Medicine, Department of Internal Medicine, V an, Turkey
}

\begin{abstract}
In this study, the hematological and biochemical blood values and the differences in serum and wool trace elements (cobalt $[\mathrm{Co}]$, manganese $[\mathrm{Mn}]$, zinc $[\mathrm{Zn}]$, and selenium [Se]) were compared in healthy and livertrematode-infected sheep. A total of 100 ovines (80 trematode-infected and 20 healthy sheep) were included. The trematode-infected sheep had significantly greater $(P<0.01)$ leucocyte $(\mathrm{WBC})$, neutrophil $(\mathrm{Neu})$, and eosinophil (Eo) values and significantly lower $(P<0.01)$ erythrocyte $(\mathrm{RBC})$, hematocrit $(\mathrm{Hct})$, and hemoglobin $(\mathrm{Hb})$ values when compared with the healthy control group. The trematode-infected sheep had significantly higher serum alanine aminotransferase (ALT), aspartate aminotransferase (AST), and gamma glutamyl transferase (GGT) enzyme activity values when compared with the healthy control group $(P<0.01, P<0.05$, and $P<0.01$, respectively). Serum and wool Co, Mn, Zn, and Se levels were significantly lower $(P<0.01)$ in the trematodeinfected sheep than in the healthy control group. The effect of liver infections on trace element concentrations was determined to be similar in measurements in wool and serum. Decreases in trace element concentrations were mostly attributed to changes in the biotransformation of trace elements induced by pathologic disorders in the liver.
\end{abstract}

Keywords: Liver-trematode, Serum, Sheep, Trace element, Wool.

\section{Karaciğer Trematodlu Koyunların Serum ve Yapağılarında Kobalt, Mangan, Selenyum ve Çinko Düzeylerinin Araştırılması}

\section{ÖZ}

$\mathrm{Bu}$ çalışmada sağliklı ve karaciğer trematodu ile enfekte olmuş koyunlarda hematolojik ve biyokimyasal kan değerleri ile serum ve yün eser elementlerindeki (kobalt [Co], mangan [Mn], çinko [Zn] ve selenyum [Se]) farklılıklar karşılaştırılmıştır. Bu amaçla 80 baş karaciğer trematodlu ve 20 baş da sağlıklı olmak üzere toplam 100 baş koyun kullanıldı. Karaciğer trematodlu koyunların lökosit (WBC), nötrofil (Neu) ve eozinofil (Eo) düzeyleri kontrol grubunun aynı parametrelerinden istatistiki olarak önemli düzeyde yüksek $(\mathrm{P}<0,01)$ tespit edilirken, eritrosit $(\mathrm{RBC})$, hematokrit $(\mathrm{Hct})$ ve hemoglobin $(\mathrm{Hb})$ değerleri daha düşük $(\mathrm{P}<0,01)$ bulunmuştur. Karaciğer trematodlu koyunların alanin aminotransferaz (ALT), aspartat aminotransferaz (AST) ve gamma glutamil transpeptidaz (GGT) değerleri sağlıklı koyunların aynı parametrelerine göre sırasiyla $\mathrm{P}<0,001, \mathrm{P}<0,005$ ve $\mathrm{P}<0,001$ düzeylerinde yüksek tespit edildi. Karaciğer trematodlu koyunların serum ve yün $\mathrm{Co}, \mathrm{Mn}, \mathrm{Zn}$ ve Se seviyeleri sağllklı koyunlara göre istatistiksel olarak önemli düzeyde düşük bulunmuştur $(\mathrm{P}<0,01)$. Karaciğer enfeksiyonlarının iz element konsantrasyonları üzerindeki etkisinin yün ve serumdaki ölçümlerinin benzerlik gösterdiği saptanmıştır. Karaciğer trematodlu koyunların serum ve yün iz elementlerin konsantrasyonundaki düşüşlerin karaciğerdeki patolojik bozukluklarına bağlı olarak oluşan iz elementlerin biyotransformasyonundaki değişimlerinde kaynaklanabileceği düşünülmektedir.

Anahtar Kelimeler: Karaciğer trematodu, Serum, Koyun, İz element, Yün.

To cite this article: Tuncer S.S. Denizhan V. Kozat S. Investigation of Serum and Wool Levels of Cobalt, Manganese, Selenium and Zinc in Liver-Trematode-Infected Sheep. Kocatepe Vet J. (2020) 13(2):185-191 


\section{INTRODUCTION}

Liver trematode infections decrease animal growth, reduce yields, suppress the immune system, and ultimately cause death in cases of severe infection. Consequently, these infections generate significant economic losses every year (Levieux et al. 1992, Matanovic et al. 2007). Trematodes migrating to the liver may deplete potential glycogen reservoirs, as the liver is the primary glycogen depot of animals, so these parasites can cause severe destruction of hepatocytes (Phiri et al. 2007, Kozat and Denizhan 2010). The most precise indicators of the level of liver cell damage in liver diseases, including trematode infections, are the activities of glutamate dehydrogenase (GLDH) and gamma glutamyl transferase (GGT) (Kozat et al. 2006, Mert et al. 2006, Kozat and Denizhan 2010). Plasma GLDH and GGT activities are therefore considered better and more sensitive indicators of liver cell damage, such as that caused by sub-clinical and chronic fascioliasis, when compared to aspartate aminotransferase (AST) activity (Sykes et al. 1980). In general, GGT might be more appropriate for the diagnosis of liver cell damage due to its greater stability.

A healthy liver is essential for the preservation of animal health and growth performance (ChalabisMazurek and Walkuska 2014). In particular, the liver organ plays a central role in the use and distribution of macro and micro elements absorbed from the intestines, and animal health depends on sufficient and well-balanced trace element concentrations. The serum cobalt $(\mathrm{Co})$ and zinc $(\mathrm{Zn})$ levels in ruminant animals are directly related to the $\mathrm{Co}$ and $\mathrm{Zn}$ concentrations of the animals diets (Jacob 1987, Oldfield 1987). These two trace elements play significant roles in hair follicle maturation, ovulation, and the estrus cycle (Unal 1987), so their deficiencies can generate significant animal yield losses and consequent economic losses for growers (Şendil et al. 1975, Jacob 1987, Aytuğ et al. 1990). Zn, in particular, serves as a cofactor for more than 300 enzymes and plays a substantial role in growth, DNA synthesis, immune system performance, neuro-sensory functions, and several other cellular process in both humans and animals (Kozat 2007). Zn deficiency reduces cell division and appetite, decreases growth and development, and generates parakeratosis lesions over the skin (Kaneko et al. 1997). $\mathrm{Zn}$ is present in all animal tissues and particularly in muscles, bones, blood, glands, genital organs, skin, hair, wool, and nails (Gabor 1991).

Cobalt is an essential trace element in ruminants, as it is required for vitamin $\mathrm{B}_{12}$ synthesis in the rumen. Unlike the case in other domesticated animals, this vitamin is synthesized by the microorganisms of the ruminant proventriculus, so sufficient quantities of cobalt are required in the diet (Stangl et al. 1999). Co absorption is quite low in ruminants, and only $3 \%$ of the Co taken up is synthesized into vitamin $\mathrm{B}_{12}$ and only $3 \%$ of the synthesized vitamin $\mathrm{B}_{12}$ is absorbed (NCR 1987). Vitamin $B_{12}$ synthesis by microorganisms is totally inhibited when the Co content of the rumen fluid is less than $0.5 \mathrm{ng} / \mathrm{ml}$ (Underwood 1977). The trace element concentrations are significantly lower in sheep with liver cystic echinococcosis than in healthy sheep $(P<0.01)$ (Taşç1 et al. 1995). Decreases in serum trace element levels also occur in animals afflicted with parasitic diseases, mostly due to malnutrition, transfer of parasites to other sections of the body, or substantial uptake of these elements by the parasites (Seyrek et al. 2009).

Manganese is also an essential trace element for animals (Kozat 2007). It is required for the activity of glucoside enzymes that form the mucopolysaccharide chondroitin that is involved in cartilage, cartilage activity, and bone formation (Miranda et al. 2006). Absorption of $\mathrm{Mn}$ in the gastrointestinal tract depends on its chemical form. Absorbed $\mathrm{Mn}$ is initially transported to the liver and then secreted into the intestines with the gall. The Mn secreted into intestines is reabsorbed through the enterohepatic cycle. The absorbed Mn is initially sequestered in the mitochondria of the liver, kidneys, and pancreas. About $40 \%$ of the body $\mathrm{Mn}$ is preserved in the bone marrow (Kozat 2007).

Selenium is another important biochemical component, as it forms part of the structure of glutathione peroxidase enzyme. Together with vitamin $\mathrm{E}$, this enzyme inhibits oxidative processes that destroy cells and tissues (Değer et al. 2008).

The trace element contents of animal tissues are determined from serum, wool, hair, and liver and kidney tissues (Bayşu et al. 1984). Determination of mineral levels can aid in determining preventive health measures, thereby maintaining high animal yields (Spears 2003), so several studies have investigated the relationships of trace element deficiencies with these yields (White et al. 1994). In sheep, trace element deficiencies result in yield losses, fleece abnormalities, and various malnutritional problems (Kozat 2007). Minerals taken up by the animal, together with vitamins, play critical roles in the healthy development of fetuses and young, in the improvement of yield and resistance, in the sustainability of production, and in the performance of various metabolic functions. Trace elements, and especially those with co-factor roles, are of significant importance for the functions of metalloenzymes (Şendil et al. 1975, Jacob 1987).

The deficiency or abundance of trace elements can therefore result in a number of functional disorders (Aytuğ et al. 1990). In the present study, changes in serum and wool trace element concentrations were 
investigated in sheep with disorders in the liver induced by liver trematode infection. According to the results of the research, it is thought that the determination of trace element in wool instead of serum in animals with liver infection will be beneficial for animal welfare.

\section{MATERIAL and METHODS}

\section{Animals and Sampling}

The final report of this research study was approved (2017/12) by Van Yuzuncu Yil University Animal Researches Local Ethic Committee. This study was conducted on 8 sheep farms with an average size of 200-280 ewes. Animal feces samples were analyzed to select 80 sheep with trematode infection and 20 healthy sheep. This selection was conducted by collecting 30-50 g feces samples from the rectums into sample cups and analyzing them in the laboratory using the Benedek Sedimentation method (Toparlak and Tüzer 1994). After taking feces and blood samples, $10 \mathrm{mg} / \mathrm{kg}$ triclabendazole $+7.5 \mathrm{mg} / \mathrm{kg}$ levamisole were administered orally to sheep infected with tremadotes.

From blood-sampled sheep, wool samples (about $5 \mathrm{~g}$ ) were also taken from the occipital area with steel scissors. While taking the wool samples, the wool was cut only from the bottom to eliminate potential differences in $\mathrm{Co}, \mathrm{Mn}, \mathrm{Se}$, and $\mathrm{Zn}$ concentrations in the top, middle, and bottom sections of the wool. Samples were placed into polyethylene bags and kept sealed until analysis.

\section{Laboratory Analyses}

Blood samples were taken from trematode-infected and healthy sheep in accordance with the relevant techniques for hematologic and biochemical analyses. Samples were collected into anticoagulant tubes and analyzed for hematocrit value (Hct), hemoglobin concentration $(\mathrm{Hb})$, and leucocyte (WBC), erythrocyte (RBC), eosinophil (Eo), and neutrophil $(\mathrm{Neu})$ ratios with a veterinary hemogram device (Veterinary MS4-s-Melet Schloesing Laboratories in France) in the Animal Hospital laboratory.

\section{Biochemical Analyses}

Blood samples collected into non-anticoagulant tubes (biochemistry tubes) were centrifuged at 3000 rate per minute (rpm) for 10 minutes to obtain blood sera, which were then stored in serum preservation tubes in a fridge at $-20{ }^{\circ} \mathrm{C}$ until biochemical analysis (Özdemir et al. 2014). Serum AST, alanine aminotransferase (ALT), and GGT levels were measured with autoanalyzer device (BS-120 VetMindray). Serum Co, Mn, Zn, and Se concentrations were measured with an Inductively Coupled Plasma Mass Spectrometer (ICP-MS) instrument in the Scientific Research Center of University.

\section{Analysis of Wool Samples}

Wool samples were initially washed with a $1 \%$ TritonX 100 solution four times and then rinsed with double distilled deionized water. The washed samples were then dried in a sterilizer at $100{ }^{\circ} \mathrm{C}$ for two hours. About $100 \mathrm{mg}$ of the dried wool samples were placed into tubes, $1 \mathrm{ml}$ of a 1:5 nitric acid + perchloric acid mixture was added, and the samples were allowed to dissolve for four hours. The dissolved mixtures were made up to $10 \mathrm{ml}$ with distilled water. From this mixture, $1 \mathrm{ml}$ was removed and diluted with $2 \mathrm{ml}$ distilled water. The prepared and diluted (1:30) wool samples were then subjected to $\mathrm{Co}, \mathrm{Mn}, \mathrm{Zn}$, and Se analyses with an ICP-MS instrument in the Scientific Research Center of University (Kozat 2007).

\section{Statistical Analysis}

Statistical analyses were performed using the GLM sub-procedure of the SAS 9.4 statistical software (SAS 2018). Data from serum and wool samples were subjected to variance analysis, and significant means were compared with Duncan's multiple range test.

\section{RESULTS}

\section{Clinical Results}

Inspections of the feces revealed Fasciola hepatica and Dicrocoelium dendriticum eggs. The trematode-infected sheep showed inappetence, weight loss, poor performance, reductions in milk yield and fleece quality, and digestive disorders; some sheep had diarrhea and anemia.

\section{Hematological Results}

Data for hematological parameters of the trematodeinfected and healthy sheep are provided in Table 1. The WBC, Neu, and Eo levels were significantly higher in the trematode-infected sheep (13.91, 9.28, and 0.73 , respectively) than in the control group (8.60, 5.80, and 0.18 , respectively) $(P<0.01)$, but the $\mathrm{RBC}\left(\times 10^{6} \mu \mathrm{L}\right)$, Hct $(\%)$, and $\mathrm{Hb}(\mathrm{g} / \mathrm{dl})$ values were lower in the infected sheep $(9.80,25.90$, and 9.75, respectively) than in control group (11.80, 33.00, and 13.41, respectively) $(P<0.01)$.

\section{Biochemical Results}

Statistical analysis results for blood serum biochemical parameters of infected and healthy sheep are provided in Table 2 . The ALT $(30.60 \mathrm{U} / \mathrm{L})$, AST $(148.25 \mathrm{U} / \mathrm{L})$, and GGT $(80.44 \mathrm{U} / \mathrm{L})$ values were significantly greater in the trematode-infected sheep than in the healthy sheep $(17.70 \mathrm{U} / \mathrm{L}, 94.20 \mathrm{U} / \mathrm{L}$, and $54.20 \mathrm{U} / \mathrm{L}$, respectively; $P<0.01, P<0.05$, and $P<0.01$, respectively).

Data for the serum mineral levels of trematodeinfected and healthy sheep are provided in Table 3. The serum Co, Mn, Se and $\mathrm{Zn}$ levels were significantly lower $(P<0.01)$ in the infected sheep $(2.50 \mu \mathrm{g} / \mathrm{dl}, 31.00 \mu \mathrm{g} / \mathrm{dl}, 2.73 \mu \mathrm{g} / \mathrm{dl}, 31.12 \mu \mathrm{g} / \mathrm{dl}$, 
respectively) than in the healthy controls $(4.90 \mu \mathrm{g} / \mathrm{dl}$, $58.00 \mu \mathrm{g} / \mathrm{dl}, 4.69 \mu \mathrm{g} / \mathrm{dl}, 83.76 \mu \mathrm{g} / \mathrm{dl}$, respectively).

Data for the wool mineral levels of trematodeinfected and healthy sheep are provided in Table 4. The mineral (Co, Mn, Se and $\mathrm{Zn}$ ) levels were significantly lower $(P<0.01)$ in the infected sheep $(0.03 \mu \mathrm{g} / \mathrm{g}, 4.22 \mu \mathrm{g} / \mathrm{g}, 1.35 \mu \mathrm{g} / \mathrm{g}$ and $26.71 \mu \mathrm{g} / \mathrm{g}$, respectively) than in the healthy controls $(0.06 \mu \mathrm{g} / \mathrm{g}$, $10.61 \mu \mathrm{g} / \mathrm{g}, 4.66 \mu \mathrm{g} / \mathrm{g}$ and $45.96 \mu \mathrm{g} / \mathrm{g}$, respectively).

The correlations between serum trace element levels of the healthy sheep are provided in Table 5 . Significant positive correlations were observed between Se and Co $(0.948 ; P<0.01)$ and significant negative correlations were observed between Se and Zn $(-0.647 ; P<0.05)$.

The correlations between serum trace element levels of the trematode-infected sheep are provided in Table 6. Significant positive correlations were observed between Se and $\mathrm{Zn}(0.340 ; P<0.01)$, and significant negative correlations were observed between $\mathrm{Zn}$ and $\mathrm{Mn}(-0.624 ; P<0.01)$ and between Se and $\mathrm{Mn}$ ($0.227 ; P<0.05)$. No significant correlations were noted between the wool trace element levels in healthy sheep (Table 7). The correlations between wool trace element levels of liver trematode-infected sheep are provided in Table 8 . Significant positive correlations were noted between $\mathrm{Zn}$ and $\mathrm{Mn}(0.449$; $P<0.01)$ and between $\mathrm{Zn}$ and $\mathrm{Se}(0.521 ; P<0.01)$.

Table 1. Hematologic blood parameters of healthy control sheep and sheep infected with liver trematodes

\begin{tabular}{lcc}
\hline Parameter & $\begin{array}{c}\text { Control } \\
(\mathbf{n}=\mathbf{2 0})\end{array}$ & $\begin{array}{c}\text { Trematode } \\
\text { infected }(\mathbf{n}=\mathbf{8 0})\end{array}$ \\
\hline $\mathrm{WBC}\left(\mathrm{x} 10^{3} / \mu \mathrm{l}\right)$ & $8.60 \pm 0.60^{\mathrm{a}^{* *}}$ & $13.91 \pm 2.27^{\mathrm{b}}$ \\
$\mathrm{Neu}(\%)$ & $5.80 \pm 0.34^{\mathrm{a}^{* *}}$ & $9.28 \pm 1.58^{\mathrm{b}}$ \\
$\mathrm{Eo}(\%)$ & $0.18 \pm 0.03^{\mathrm{a}^{* *}}$ & $0.73 \pm 0.06^{\mathrm{b}}$ \\
$\mathrm{RBC}\left(\mathrm{x} 10^{6} \mu \mathrm{l}\right)$ & $11.80 \pm 0.50^{\mathrm{a}^{* *}}$ & $9.80 \pm 0.48^{\mathrm{b}}$ \\
$\mathrm{Hct}(\%)$ & $33.00 \pm 2.27^{\mathrm{a}^{* *}}$ & $25.90 \pm 2.33^{\mathrm{b}}$ \\
$\mathrm{Hb}(\mathrm{g} / \mathrm{dl})$ & $13.41 \pm 1.33^{\mathrm{a}^{* *}}$ & $9.75 \pm 1.76^{\mathrm{b}}$ \\
\hline
\end{tabular}

a, b: Means with different lower case letters in the same row are significantly different

${ }^{* *}: P<0.01$

WBC: leucocyte, Neu: neutrophil, Eo: eosinophil, RBC: erythrocyte, Hct: hematocrit, Hb: hemoglobin.

Table 2. Biochemical parameters of healthy control sheep and sheep infected with liver trematodes

\begin{tabular}{lcc}
\hline Parameter & $\begin{array}{c}\text { Control } \\
(\mathbf{n}=\mathbf{2 0})\end{array}$ & $\begin{array}{c}\text { Trematode infected } \\
(\mathbf{n}=\mathbf{8 0})\end{array}$ \\
\hline ALT (U/L) & $17.70 \pm 2.32^{\mathrm{a}^{* *}}$ & $30.60 \pm 6.15^{\mathrm{b}}$ \\
AST (U/L) & $94.20 \pm 18.79^{\mathrm{a}^{*}}$ & $148.25 \pm 60.14^{\mathrm{b}}$ \\
GGT (U/L) & $54.20 \pm 5.55^{\mathrm{a}^{* *}}$ & $80.44 \pm 16.12^{\mathrm{b}}$ \\
\hline
\end{tabular}

a, b: Means with different lower case letters in the same row are significantly different

${ }^{*}: P<0.05 ;{ }^{* *} P<0.01$

ALT: alanine aminotransferase, AST: aspartate aminotransferase, GGT: gamma glutamyl transferase.
Table 3. Serum trace element levels in healthy control sheep and sheep infected with liver trematodes

\begin{tabular}{ccc}
\hline Parameter & $\begin{array}{c}\text { Control } \\
(\mathbf{n}=\mathbf{2 0})\end{array}$ & $\begin{array}{c}\text { Trematode infected } \\
(\mathbf{n}=\mathbf{8 0})\end{array}$ \\
\hline $\mathrm{Co}(\mu \mathrm{g} / \mathrm{dl})$ & $4.90 \pm 0.80^{\mathrm{a}^{* *}}$ & $2.50 \pm 0.50^{\mathrm{b}}$ \\
$\mathrm{Mn}(\mu \mathrm{g} / \mathrm{dl})$ & $58.00 \pm 5.10^{\mathrm{a}^{* *}}$ & $31.00 \pm 0.10^{\mathrm{b}}$ \\
$\mathrm{Se}(\mu \mathrm{g} / \mathrm{dl})$ & $4.69 \pm 1.20^{\mathrm{a}^{*}}$ & $2.73 \pm 1.29^{\mathrm{b}}$ \\
$\mathrm{Zn}(\mu \mathrm{g} / \mathrm{dl})$ & $83.76 \pm 43.64^{\mathrm{a}^{*}}$ & $31.12 \pm 10.32^{\mathrm{b}}$ \\
\hline
\end{tabular}

a, b: Means with different lower case letters in the same row are significantly different

${ }^{*}: P<0.05 ;{ }^{* *} P<0.01$

Co: cobalt, Mn: manganese, Zn: zinc, Se: selenium.

Table 4. Wool trace element levels in healthy control sheep and sheep infected with liver trematodes

\begin{tabular}{ccc}
\hline Parameter & $\begin{array}{c}\text { Control } \\
(\mathbf{n}=\mathbf{2 0})\end{array}$ & $\begin{array}{c}\text { Trematode infected } \\
(\mathbf{n}=\mathbf{8 0})\end{array}$ \\
\hline $\mathrm{Co}(\mu \mathrm{g} / \mathrm{g})$ & $0.06 \pm 0.01^{\mathrm{a}^{* *}}$ & $0.03 \pm 0.01^{\mathrm{b}}$ \\
$\mathrm{Mn}(\mu \mathrm{g} / \mathrm{g})$ & $10.61 \pm 3.89^{\mathrm{a}^{* *}}$ & $4.22 \pm 1.78^{\mathrm{b}}$ \\
$\mathrm{Se}(\mu \mathrm{g} / \mathrm{g})$ & $4.66 \pm 2.17^{\mathrm{a}^{* *}}$ & $1.35 \pm 0.50^{\mathrm{b}}$ \\
$\mathrm{Zn}(\mu \mathrm{g} / \mathrm{g})$ & $45.96 \pm 16.62^{\mathrm{a}^{* *}}$ & $26.71 \pm 12.80^{\mathrm{b}}$ \\
\hline
\end{tabular}

a, b: Means indicated with different small letters in the same row are significantly different

${ }^{* *}: P<0.01$.

Table 5. Correlations between serum trace element levels of healthy sheep

\begin{tabular}{lllll}
\hline & Co & Mn & Se & Zn \\
\hline Co & 1 & & & \\
Mn & -0.123 & 1 & & \\
Se & $0.948^{* *}$ & -0.297 & 1 & \\
$\mathbf{Z n}$ & -0.534 & 0.362 & $-0.647^{*}$ & 1 \\
${ }^{*}: P<0.05 ;{ }^{* *}: P<0.01$. & & &
\end{tabular}

Table 6. Correlations between serum trace element levels of trematode-infected sheep

\begin{tabular}{lllll}
\hline & Co & Mn & Se & Zn \\
\hline Co & 1 & & & \\
Mn & 0.164 & 1 & & \\
Se & 0.019 & $-0.227^{*}$ & 1 & \\
$\mathbf{Z n}$ & -0.113 & $-0.624^{* *}$ & $0.340^{* *}$ & 1 \\
\hline${ }^{*}: P<0.05 ;{ }^{* *}: P<0.01$. & & &
\end{tabular}

Table 7. Correlations between wool trace element levels in healthy sheep

\begin{tabular}{lllll}
\hline & Co & Mn & Se & Zn \\
\hline Co & 1 & & & \\
Mn & -0.128 & 1 & & \\
Se & -0.236 & 0.493 & 1 & \\
Zn & -0.090 & 0.169 & 0.496 & 1 \\
\hline
\end{tabular}

Table 8. Correlations between wool trace element levels in liver trematode-infected sheep

\begin{tabular}{lllll}
\hline & Co & Mn & Se & Zn \\
\hline Co & 1 & & & \\
Mn & -0.120 & 1 & & \\
Se & 0.094 & 0.069 & 1 & \\
Zn & -0.210 & $0.449^{* *}$ & $0.521^{* *}$ & 1 \\
\hline${ }^{* *}: P<0.01$. & & &
\end{tabular}




\section{DISCUSSION}

The RBC, Hct, and $\mathrm{Hb}$ values were lower in the trematode-infected sheep than in the healthy sheep (Table 1), in agreement with the literature (Vengust et al. 2003; Samadieh et al. 2017). Of the hematological parameters of healthy and trematode-infected sheep, the WBC, RBC, Hct, and $\mathrm{Hb}$ levels were in compliance with the reference values specified for sheep, whereas the Neu and Eo levels were lower than the reference values (Babeker and Elmansoury 2013).

The higher ALT, AST, and GGT levels in the trematode-infected sheep than in the healthy sheep (Table 2) can be attributed to enzyme leakage from destroyed organs (Gerber 1969). Increasing AST and ALT activities have been reported previously in lambs infected with 1000 and 3000 metacercariae of $D$. dendriticum (Manga-González et al. 2004). The ALT, AST, and GGT values of the trematode-infected sheep in the present study were similar to those reported in the literature for liver parasite infections (Mert et al. 2006, Kozat and Denizhan 2010). The ALT, AST, and GGT values of the healthy sheep were also in compliance with the values reported in similar studies (Kozat and Denizhan 2010, Samadieh et al. 2017). The mean GGT value for the trematodeinfected sheep $(80.44 \mathrm{U} / \mathrm{L})$ was greater than the specified reference values (20-52 U/L), but the GGT value for the healthy sheep $(54.20 \mathrm{U} / \mathrm{L})$ was similar to the reference values. The ALT $(17.70 \mathrm{U} / \mathrm{L}$ and 30.60 $\mathrm{U} / \mathrm{L})$ and AST $(94,20 \mathrm{U} / \mathrm{L}$ and 148,25 U/L) values of the healthy and infected animals were in compliance with the normal reference values (26-34 U/L and 60$280 \mathrm{U} / \mathrm{L}$, respectively) (Kahn and Line 2011).

Trace elements are micronutrients necessary for the growth and preservation of healthy tissues. Blood is a medium where trace elements are collected and transported. Therefore, serum is usually a suitable sample for determining the trace element status of animals (Özdemir et al. 2014). However, mineral measurements from tissue, hair, or wool may provide more accurate results than serum analyses (Bayşu et al. 1984).

Serum and wool trace element (Co, Mn, Se and $\mathrm{Zn}$ ) levels were significantly lower $(P<0.01)$ in the trematode-infected sheep than in the healthy sheep (Table 3 and Table 4). No studies in the literature have reported the trace element levels of parasiteinfected sheep. However, decreasing serum trace element levels have been reported in parasitic diseases (Taşç1 et al. 1995, Seyrek et al. 2009). Decreases in serum trace element concentrations in animals subjected to parasite infections are mostly attributed to malnutrition, transfer of trace elements to other parts of the body, and/or high uptake of these elements by the parasites (Seyrek et al. 2009).
The serum $\mathrm{Zn}$ levels in the healthy sheep (83.76 $\mu \mathrm{g} / \mathrm{dl}$ ) (Table 3) were in compliance with the reference values $(80-150 \mu \mathrm{g} / \mathrm{dl}$ ) (Kurt et al. 2001, Erdoğan et al. 2002), but the serum $\mathrm{Zn}$ levels in the trematode-infected sheep $(31.12 \mu \mathrm{g} / \mathrm{dl})$ (Table 3) were lower than the reference values. Decreasing plasma Zn levels were observed in echinococcosis diseases (Heidarpour et al. 2012), in response to the accelerated metabolism of animals during the progression of disease (Beisel 1991), and in insufficient nutrition, stress, and hyperthermia cases (Heidarpour et al. 2012). Another study reported that serum $\mathrm{Zn}$ levels decreased in parasitic diseases (Taşç1 et al. 1995). The low $\mathrm{Zn}$ levels observed in the trematode-infected sheep in the present study were also attributed to these reasons.

The serum Co concentrations in the healthy control group $(4.90 \mu \mathrm{g} / \mathrm{dl})$ (Table 3) were within the reference value range. The observed decreases in Co concentrations in the trematode-infected sheep (2.50 $\mu \mathrm{g} / \mathrm{dl}$ ) (Table 3) agreed with the available literature (Taşç1 et al. 1995, Seyrek et al. 2009).

The serum Se levels were significantly greater in the healthy sheep $(4.69 \mu \mathrm{g} / \mathrm{dl})$ than in the trematodeinfected sheep $(2.73 \mu \mathrm{g} / \mathrm{dl})(P<0.05)$ (Table 3$)$. The serum Se levels of healthy sheep were in compliance with the values specified for sheep, at $5.37 \mu \mathrm{g} / \mathrm{dl}$ (Yokus et al. 2004), and for lambs, between $6.0 \mu \mathrm{g} / \mathrm{dl}$

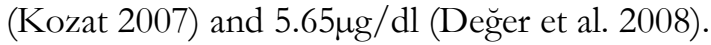

Decreasing plasma $\mathrm{Zn}$ levels were reported in Echinococcus-infected camels (Heidarpour et al. 2012), during the disease periods of animals (Beisel 1991), in animals with insufficient $\mathrm{Zn}$ nutrition, and in stress and hyperthermia cases (Heidarpour et al. 2012). In the present study, low $\mathrm{Zn}$ concentrations were determined in sheep infected with liver trematodes $(31.12 \mu \mathrm{g} / \mathrm{dl}$ ) (Table 3), in agreement with previous reports (Beisel 1991, Taşç1 et al. 1995, HumannZiehank et al. 2008, Heidarpour et al. 2012).

\section{CONCLUSIONS}

In conclusion, highly significant decreases were observed in blood serum Co and Mn levels $(P<0.01)$ and significant decreases were observed in Se and $\mathrm{Zn}$ levels in sheep infected with liver trematodes $(P<0.05)$, with highly significant decreases observed all trace element levels in wool $(P<0.01)$. The effect of liver infections on trace element concentrations was determined to be similar in measurements in wool and serum. This result shows that trace elements can be determined in wool instead of serum for animal welfare. Decreases in trace element concentrations were mostly attributed to changes in the biotransformation of trace elements induced by pathologic disorders in the liver. 


\section{ACKNOWLEDGEMENT}

This study was supported by Research Fund of the Van Yuzuncu Yil University. Project number FBA-2018-6823.

The final report of this research project was approved by $V$ an Yuzuncu Yil University Animal Research Local Etbic Committee, decision number 2017/12.

Conflict of Interest: The authors declare that they have no conflict of interest.

\section{REFERENCES}

Aytuğ CN, Alaçam E, Özkoç U, Yalçın BC, Gökçen H, Türker H. Sheep - Goat diseases and breeding. Tüm Vet Hay Hizm Yay, İstanbul, Turkey. 1990; 2: 289-301.

Babeker EA, Elmansoury YHA. Observations concerning haematological profile and certain biochemical in Sudanese Desert goat. Online J Anim Feed Res. 2010; 3(1): 80-86.

Bayşu N, Dündar Y, Bayrak S. The relationship between copper levels in wool and blood of sheep and lambs and its diagnostic importance. Doğa Bil Derg. 1984; 8(1): 117-122.

Beisel WR. Nutrition and infection, In; Nutritional Biochemistry and Metabolism with Clinical Application, Ed; Linder MC, $2^{\text {nd }}$ Ed., Elsevier, New York, USA. 1991; pp. 507542.

Chalabis-Mazurek A, Walkuska G. Effect of different forms of selenium on trace elements in the blood serum and liver tissue of lambs. J Elem. 2014; 19(1): 41-53.

Değer Y, Mert H, Mert N, Yur F, Kozat S, Yörük İH, Sel T. Serum selenium, vitamin $\mathrm{E}$, and sialic acids concentrations in lambs with white muscle disease. Biol Trace Elem Res. 2008; 121(1): 39-43.

Erdoğan S, Ergün Y, Erdoğan Z, Kontaş T. Some mineral substance levels in serum of sheep and goat grazing in Hatay Region. Turk J Vet Anim Sci. 2002; 26: 177-182.

Gabor S. Trace elements and lipid peroxidation. Trace elements in health and disease. ÇÜ Pub Trace. 89, Adana, Turkey. pp. 273-277.

Gerber H. Serum enzyme determination in equine medicine. Equine Vet J. 1969; 1(3): 129-139.

Heidarpour M, Mohri M, Borji H, Moghdass E. Oxidative stress and trace elements in camel (Camelus dromedarius) with liver cystic echinococcosis. Vet Parasitol. 2012; 187(3-4): 459-463.

Humann-Ziehank E, Ganter M, Hennig-Pauka I, Binder A. Trace mineral status and liver and blood parameters in sheep without mineral supply compared to local roe deer (Capreolus capreolus) populations. Small Rumin Res. 2008; 75(2-3): 185-191.

Jacob RA. Trace elements, In; Textbook of Clinical Chemistry, Ed;Tietz NN and Saunders WB, Philadelphia, USA. 1987; pp. 965-978.

Kahn CM, Line S. The Merck veterinary manual. 10th Ed., 2 nd print, Merck and Co., Whitehouse Station, Great Britain. 2011; p. 2945

Kaneko JJ, Harvey JW, Bruss ML. Clinical Biochemistry of Domestic Animals. 5th Ed., Academic Press. California, USA. 1997; p. 932.
Kozat S. Importance, necessity and the effects of deficiencies of trace elements in ruminants. YYU Health Sci J. 2007; 10: $58-67$.

Kozat S, Denizhan V. Glucose, lipid, and lipoprotein levels in sheep naturally infected with Fasciola hepatica. J Parasitol. 2010; 96(3): 657-659.

Kozat S, Ekin S, Kaya A, Denizhan V. Serum adenosine deaminase activity and selected biochemical parameters in chronic fascioliasis in sheep. Indian Vet J. 2006; 83, 249_ 350 .

Kurt D, Denli O, Kanay Z, Güzel C, Ceylan K. An investigation of the copper $(\mathrm{Cu})$, zinc $(\mathrm{Zn})$ and selenium (Se) levels of blood serum and the $\mathrm{Cu}$ and $\mathrm{Zn}$ levels of wool of Akkaraman ewes in the Diyarbakır region. Turk J Vet Anim Sci. 2001; 25(4): 431-436.

Levieux D, Levieux A, Mage C, Venien A. Early immunodiagnosis of bovine fascioliasis using the specific antigen $\mathrm{f} 2$ in a passive hemagglutination test. Vet Parasitol. 1992; 44: 77-86.

Manga-González MY, Ferreras MC, Campo R, GonzálezLanza C, PérezV, García-Marín JF. Hepatic marker enzymes, biochemical parameters and pathological effects in lambs experimentally infected with dicrocoelium dendriticum. Parasitol Res. 2004; 93(5): 344-55.

Matanovic K, Severin K, Martinkovic' F, Simpraga M, Janicki Z, Barisic J. Hematological and biochemical changes inorganically farmed sheep naturally infected with Fasciola hepatica. Parasitol Res. 2007; 101: 1657 1661.

Mert H, Kozat S, Ekin S, Yoruk IH. Serum sialic acid, lipidbound sialic acid levels in sheep naturally chronic infected with Fasciola hepatica. YYU Health Sci J. 2006; 2: 40-46.

Miranda M, Alonso ML, Benedito JL. Copper, zinc, iron, and manganese accumulation in cattle from Asturias (northern Spain). Biol Trace Elem Res. 2006; 109(2): 135-143.

NCR. Vitamin Tolerance of Animals. The National Academy Press, Washington DC, USA. 1987; p. 108.

Oldfield EJ. The two faces of selenium. J Nutr. 1987; 117: 2002 2008.

Özdemir HS, Karadaş F, Yörük İ, Oto G, Erdemoğlu E, Yeşilova A. Vitamin and Mineral Levels of Newborns in Van Basin and Their Relation to Maternal Vitamin and Mineral Status. Open J Pediatr. 2014; 4: 107-114.

Phiri K, Phiri AM, Harrison LJ. The serum glucose and betahydroxybutyrate levels in sheep with experimental Fasciola hepatica and Fasciola gigantica infection. Vet Parasitol. 2007; 143: 287-293.

Samadieh H, Mohammadi GR, Maleki M, Borji H, Azizzadeh M, Heidarpour M. Relationships between oxidative stress, liver, and erythrocyte injury, trace elements and parasite burden in sheep naturally infected with dicrocoelium dendriticum. Iran J Parasitol. 2017; 12(1): 46-55.

SAS, Statistical Analysis System. SAS/STAT Software: Hangen and enhanced. SAS Inst Inc, USA. 2018.

Seyrek K, Karagenc T, Pasa S, Kıral F, Atasoy A. Serum zinc, iron and copper concentrations in dogs infected with Hepatozoon canis. Acta Vet Brno. 2009; 78: 471-475.

Spears JW. Trace mineral bioavailability in ruminants. J Nut. 203; 133: 1506-1509.

Stangl GI, Schwarz FJ, Kirchgessner M. Moderate long-term cobalt-deficiency affects liver, brain and erythrocyte lipids and lipoproteins of cattle. Nutr Res. 1999; 19(3): 415- 
Sykes AR, Coop RL, Robinson MG. Chronic subclinical ovine fascioliasis: Plasma glutamate dehydrogenase, gammaglutamyl liver lipids in fatty liver of dairy cows. Anim Sci J. 1980; 77: 347-351.

Şendil Ç, Bayşu N, Ünsüren H, Çelikkan M. Studies on the presence and the incidence of enzootic ataxie in our country. FÜ Vet Fak Derg. 1975; 2(1): 38-52.

Taş̧̧ı S, Sengil AZ, Altindis M, Arisoy K. The effect of zinc supplementation in experimentally induced Toxoplasma gandii infection. J Egypt Soc Parasitol. 1995; 25: 745-751.

Toparlak M, Tüzer E. Laboratory Techniques in the Diagnosis of Parasitic Diseases. Istanbul University Faculty of Veterinary Medicine Publication, Istanbul, Turkey. 1994; p. 19.

Unal EF. Infertility in Small Ruminants, In:Birth and Infertility in Domestic Animals, Ed; Alaçam E, Medisan Yayınevi, Ankara, Turkey. 1987; pp. 195-212.

Underwood EJ. Trace Elements in Human and Animal Nutrition. $4^{\text {th }}$ Ed., Academic Press Inc., New York, USA. 1977; pp. 245-315.

Vengust G, Klinkon M, Bidovec A, Vengust A. Fasciola hepatica: effects on blood constituents and liver minerals in fallow deer (Dama dama). Vet Parasitol. 2003; 112(12): 51-61.

White CL, Martin GB, Hynd PI, Chopeman RE. The effect of zinc deficiency on wool growth and skin and wool follicle histology of male merino lambs. Br J Nutr. 1994; 71(3): 425-35.

Yokus B, Cakir DU, Kurt D. Effects of seasonal and physiological variations on the serum major and trace element levels in sheep. Biol Trace Elem Res. 2004; 101(3): 241-255. 